\title{
HIV-patients discrimination according to phenotype and functional assay of T-cells subsets
}

\author{
Marie-Paule Guillaume*, Rafik Karmali, Francis Corazza, Jean Duchateau \\ From $16^{\text {th }}$ International Symposium on HIV and Emerging Infectious Diseases \\ Marseille, France. 24-26 March 2010
}

\section{Background}

To distinguish HIV-1 patients with clinical diversity by using a simplified model of $\mathrm{T}$-cell interactions

\section{Methods}

During 28 months, 1074 blood samples from 200 HIV-1 patients and 418 blood samples from healthy blood donors were prospectively collected. $\mathrm{T}$ lymphocyte subsets and activation markers expression (CD4, CD69, CD25, CD8, CD28, HLA-DR) were determined initially and after PHA stimulation in whole blood cultures.

\section{Results}

Two step Cluster Analysis followed by a discriminant function analysis of the lymphocyte activation assay from the first blood sample, allowed the separation of HIV-1 patients in two groups: Cluster1 (67\%) and Cluster2 (33\%). Clusters definition relied on the level of three T-cells subsets: a) stimulated $\mathrm{CD} 4{ }^{+} \mathrm{CD} 69$ ${ }^{+} \mathrm{CD} 25^{\text {high }}$, b) unstimulated $\mathrm{CD} 4{ }^{+} \mathrm{CD} 69^{+} \mathrm{CD} 25^{+}$and c) unstimulated $\mathrm{CD} 4{ }^{+} \mathrm{CD} 25^{\text {high }}$. PHA stimulated CD4 ${ }^{+} \mathrm{CD} 69^{+} \mathrm{CD} 25^{\text {high }}$ subset level alone allowed to classify correctly patients with $92 \%$ sensitivity and $87 \%$ specificity. Cluster-2 expressed more CD69 and HLA-DR activation markers on $\mathrm{CD} 4$ and $\mathrm{CD} 8$ lymphocytes, less CD8 ${ }^{+} \mathrm{CD} 28^{+}$and responded less to mitogen even if viral load undetectable. Cluster-2 presented poorly clinical profile in terms of previous AIDS events, current $\mathrm{CD} 4^{+}$count, viral load, length of treatment. Over the time most patients (64\%) were keeping their cluster category.

\section{Discussion}

We propose an algorithm to identify a subset of HIV patients with an over-determined immunodeficiency status characterized by a lower ability to reverse

\footnotetext{
* Correspondence: marie-paule.guillaume@chu-brugmann.be CHU-Brugmann, Bruxelles, Belgium
}

inappropriate activation of CD4 and CD8 T-lymphocytes leading probably to earlier exhaustion of their immunological resources. This subgroup of patients could display a worst clinical evolution, lower control capacity of viral load, even under antiretroviral therapy-mediated viral suppression.

Published: 11 May 2010

doi:10.1186/1742-4690-7-S1-P26

Cite this article as: Guillaume et al:: HIV-patients discrimination according to phenotype and functional assay of T-cells subsets. Retrovirology 2010 7(Suppl 1):P26.
Submit your next manuscript to BioMed Central and take full advantage of:

- Convenient online submission

- Thorough peer review

- No space constraints or color figure charges

- Immediate publication on acceptance

- Inclusion in PubMed, CAS, Scopus and Google Scholar

- Research which is freely available for redistribution

Submit your manuscript at www.biomedcentral.com/submit
C Biomed Central 